Peer-Reviewed Article

ISSN: 2162-3104 Print/ ISSN: 2166-3750 Online

Volume 5, Issue 4 (2015), pp. 383-394

(C) Journal of International Students

http://jistudents.org/

\title{
Cultural Demands of the Host-Nation: International Student Experience and the Public Diplomacy Consequences
}

\author{
Benjamin Triana (Doctoral Candidate) \\ University of Kentucky (USA)
}

\begin{abstract}
Traditional approaches for hosting international students tend to focus on classroom achievement rather than on intercultural exchange and cultural immersion. Such approaches lessen the possibility of successful educational experiences which also hinders public diplomacy. Two case studies are presented that reveal how structural changes at a southeastern university could be modified in order to address the international student experience and 2.) How the international student experience of former Egyptian president Mohamed Morsi illustrates the need for increased emphasis on intercultural exchange due to the likelihood of international students embarking on influential political and private careers.
\end{abstract}

Keywords: international student education, intercultural dialogue, cultural immersion, public diplomacy, international relations, Mohamed Morsi

After World War II, decisions concerning American international education, both for domestic students studying abroad and international students attending American institutions, possessed this underlying philosophy: International education was "a force for peace and mutual understanding and ultimately as the means through which the United States could build and maintain its influence in the world." Through this influence, "world leaders trained in the United States would be more inclined to understand and sympathize with the United States when conducting their international affairs" (Pandit, 2009, p. 647). This ideology assumed that "peace and understanding" would also support foreign policy and security (de Witt, 2002). By the midtwentieth century, international education had become a public diplomacy approach for managing national reputation and international relations (Wang, 2006).

Based on the growth of international education exchange, nations should be aware of its potential impact on international relations. According to the Organization for Economic Cooperation and Development (OECD), there has been an increase from 3.4 million international students to 3.7 million from 2000 to 2009 (Chau, 2011). In 2010, international students attending colleges and universities in the United States increased three percent, with over thirty percent coming from China. In 2011, international student attendance jumped another 5.7 percent from the 2010 numbers (Fischer, 2010; McMurtie, 2012). With economic growth in developing 
countries, the international student demographic has become an important population to consider for economic and public diplomacy considerations.

Bellamy and Weinberg (2008) and Fulton (2007) have called for a redefinition of public diplomacy and a reforming of the practice of public diplomacy in order to address changes in the world. Public diplomacy can be defined as the ways in which non-government diplomats influence and improve relations with another nation or culture. In support of these calls, this essay argues for a holistic approach to the international student experience at higher education institutions in the United States. A more holistic approach that includes outside of the classroom intercultural dialogue and cultural immersion has the potential to increase the likelihood of successful international student experiences, and these gains are not only educational gains, but also international relations' gains.

Fulton (2007) suggested that international students that enroll in American universities are the ones in society that "make a difference" and have an "appetite for positive change" (p. 314). In the altruistic role education often plays, an improved education experience has the potential to influence the opinion international students have of the United States, and for those students that return to their home countries, these international students may influence the opinions of home country acquaintances. This reasoning is in alignment with the international relations role that both Senator J. William Fulbright and President Harry S. Truman believed international education could serve.

By considering the diplomacy role of international education, this perspective places more emphasis on intercultural exchange and cultural immersion as central components of the international education experience. Such an approach increases the likelihood of improving the international student experience as well as international relations. A review of the literature on the challenges facing international students and the characteristics of successful international student experience will highlight the cultural characteristics involved in the successful international student experiences. The literature review explicates how these challenges and characteristics parallel the cultural aspects of public diplomacy. The second half of the paper involves two case studies. The case studies are presented to provide empirical examples as to: 1.) How policy and structural changes at a southeastern university could improve the cultural exchange aspects of the international student experience, and 2.) How the international student experience of Mohamed Morsi demonstrates the importance of out-of-classroom cultural immersion in order to address issues of identity management as a result of international education exchange. The Morsi case study emphasizes the importance of positive international student experiences as international students possess a higher-than-normal potential for embarking on influential careers in government and in private business (Fulton, 2007).

\section{Conceptual Framework: Public Diplomacy and International Student Education}

Since the Fulbright Act of 1946, education has been a central component of international relations and public diplomacy. President Truman reinforced this relationship with his Commission on Higher Education which published the report, Higher Education for American Democracy (President's Commission for American Democracy, 1948). From that moment, public diplomacy has been linked to higher education and international students.

Public diplomacy can be defined as the ways in which non-government diplomats of a nation, culture, or people influence and improve relations with another nation, culture, or people (Fulton, 2007). As a part of modern diplomacy and international relations, public diplomacy is 
an essential, non-invasive attempt to influence the economic and political choices of international and intercultural cultures and nations through civic interaction. Public diplomacy is connected to the concept of soft power (Nye, 2004). Soft power is concerned with the efforts of the government or government agencies intended to influence other nations and cultures (Leonard, 2002). Through the Fulbright Act, United States' public diplomacy and soft power were linked to post-secondary international education exchanges as a viable strategy for influencing other nations and cultures.

Internationalization and globalization have increased the importance of successful international student experience as an aspect of public diplomacy. Pandit (2009) recognized the importance of the international student experience and its relationship to globalized markets, cultures, and communities: "There is a growing societal recognition that our graduates will compete in a global labor market and need to develop the ability to work more effectively in international and multicultural settings" (p. 646). To work effectively, nations and their citizens must have beneficial relationships with other nations and their citizenries. With the increased connectivity of international economic markets and the propensity of international students to hold important positions in private business, the importance of cultivating productive international relations through international student education is essential.

The next section explores what makes for a successful international student experience. It establishes the need for a more holistic and culturally focused international-student-support infrastructure. A more holistic approach addresses the out-of-classroom challenges that inhibit positive international student experiences. The section also reinforces the beneficial relationship between international student success and improved international relations.

\section{Reasons for Choosing a Host Nation, Challenges to and Successes of International Students}

In order to improve the international student experience, one must ask "What makes for a positive international student experience?" This question led to a review of why students embark on an international education, the challenges to a successful experience, and the most successful characteristics of a positive international education.

\section{Reasons for choosing a Host Country and Host Institution}

The reasons international students choose a host country have a strong connection to the cultural interactions between two nations' peoples. Reasons for choosing a specific host country and academic institution include (Mazzoral \& Soutar, 2002):

1. Knowledge and awareness of the host country.

2. Recommendations from friends and relatives.

3. Cost Issues (local ethnic communities are believed to help with costs).

4. Social Links.

5. Geographic and/or cultural proximity.

6. An institution's reputation for quality, including staff.

7. Alliances and partnerships between the institution and institutions familiar to the student.

8. Alumni base and word-of-mouth referral.

Almost all of the reasons on this list affect and are affected by intercultural interaction and ongoing diplomatic, economic, and cultural relations between the host country and an 
international student's country of origin. Recommendations from friends and relatives, social links, cultural proximity, alliances and partnerships, and alumni word-of-mouth are all dependent on positive exchanges between the populaces of two nations. Knowledge and awareness of an institution and an institution's reputation for quality can also be improved via direct international student exchange. The rationale behind selecting a host nation is linked to the international exchange between two countries.

When viewed through this lens of cultural exchange, American academic institutions with regional reputations may have an advantage in recruiting international students. While Armstrong (2007) argued that a university, "trapped in its traditional place-based identity" is at a disadvantage in international education, a regional institution has the ability to offer a unique cultural experience that cannot be replicated at any other institution (p. 134). The historical place of a university creates an opportunity for significant, place-based cultural exchange which can improve understanding and intercultural interaction as international students discover the unique culture of a specific institution, town, and people. Regional institutions can take advantage of their placed-based identity through initiatives that celebrate an institution's cultural connections that have the potential to encourage cultural immersion.

\section{Challenges International Students Face and Secrets to Success}

For institutions where the hosting of international students has only recently emerged as an aspect of their educational goals and responsibilities, identifying the challenges and the best practices for international student success is essential for establishing a successful international student program. Similar to the reasons for selecting a host institution, many of the challenges and the best practices identified in international student research is culturally-oriented.

Challenges to the international student experience have been researched extensively. Zhai (2002) found cultural differences, language adjustments, and the actual United States educational system as the most difficult obstacles to navigate. Ying and Liese (1994) reported homesickness as an important issue. In response, Tseng and Newton (2002) documented eight characteristics of a successful international student experience:

1. Knowing themselves and others.

2. Building relationships.

3. Expanding their worldview.

4. Asking for help.

5. Developing cultural and social contacts.

6. Establishing relationships with advisors and instructors.

7. English proficiency.

8. Letting go of problems.

None of the eight characteristics could be isolated as in-classroom-only or curriculum associated approaches. Conversely, none of the characteristics could be considered entirely cultural. The importance is in recognizing the fluidity and relationship of out-of-classroom and cultural/intercultural aspects of the characteristics.

The research revealed that the challenges and characteristics of international student success address out-of-the classroom issues, especially cultural understanding and intercultural exchange as well as the more traditional academic concerns. The conceptual framework and the review of the international student research led to the questions for the following case studies: 
1. How are post-secondary institutions allocating resources dedicated to hosting international students?

2. How can the allocation of resources for the hosting of international students be improved?

3. Why do some international student experiences fail to generate positive public diplomacy effects?

4. Why is it essential to generate positive public diplomacy effects with international students?

\section{Research Method}

The two case studies should be considered individual case studies as they address different level effects and are of different design (Yin, 2014). The choice to include two case studies was in response to the multiple-level functioning of intercultural communication documented by Oetzel, Dhar, and Kirschbaum (2007).

In the first case study, a southeastern university's resources and organizational structure were analyzed. The university can be classified under Armstrong's (2007) description of a reputable university with a strong regional presence and sharing the common characteristics with a large number of regional, higher-educational institutions in the United States. The strategic plan analyzed can be considered a similar representation of how strategic plans are designed for the international student experience at similar institutions.

The first case study is informed by researcher observation of international students and interviews with individuals involved in international student support. The observations and interviews were conducted over a four-year period. A subsequent document analysis of the strategic plan was conducted to corroborate the interview analysis (Lindlof \& Taylor, 2011). The first case study is primarily concerned with research questions RQ1, RQ2, and RQ3.

In the second case study, a number of published accounts of Mohamed Morsi's international student experience are analyzed to demonstrate the necessity of a more culturallyfocused approach to the international student experience. Morsi's experience demonstrates the importance of generating positive public diplomacy effects based on the likelihood of international students obtaining influential positions in their home nations (Bellamy \& Weinberg, 2008; Fulton, 2007). The second case study can be considered an extreme, unusual, and critical case (Yin, 2014).

\section{Case study 1: A Southeastern University's approach to International Students}

In 2012, a southeastern university announced that it had increased the number of international students accepted for the fall semester. Along with the increased enrollment, the institution announced the implementation of an international strategic plan in order to manage the increase in international student enrollment. The following description is a summary of the resources and strategic plan. The strategic plan is paraphrased in order to protect the institution's confidentiality.

Over 1,600 international students enroll at this university each year, and enrollment is projected to increase for the foreseeable future. International Student and Scholar Services (ISSS) and Office of International Affairs (OIA) are the two main programs that offer services for international students. The ISSS provides the following services: immigration, travel 
document advisement, work permits, transfers and extensions of stay, social programs and activities that help students learn about life on campus, opportunities for community involvement, help with language translation, and international instructional support for family members.

An additional service, the International Hospitality Program (IHP), focuses on adaptation, assimilation and intercultural relations-management for international students once they arrive. Along with IHP, the university offers a Cultural Coffee Hour, a cross-cultural workshop for undergraduates expecting to work for international companies, an international buddy program, and a multi-organizational Cultural Diversity Festival to increase cultural awareness. In support of these activities, the university also offers a listserv and an online calendar for students to remain informed on International Affairs' sponsored events. The university also offers services for dependents. The university offers educational support for dependent children including a Japanese Saturday School and K-12 Educational Initiatives. There is an English as a Second Language Center for language reinforcement.

There are two other services that support the international student experience at this particular university. First, ESL instructors are involved in cultivating positive experiences for international students (University ESL instructor, personal communication, December 3, 2012; University ESL instructor, personal communication, December 4, 2012). ESL instructors encourage students to increase involvement in official university functions through extra credit opportunities and class curricula. Secondly, depending on the ethnic community and informal efforts, students are assigned mentors to help with culture shock and adaptation (University ESL instructor, personal communication, December 4, 2012).

Still, a lack of international student integration persists. International Student Council meetings and events are not attended by international or domestic students. This issue has led to concerns over the actual intercultural interaction and cultural exchange occurring between international and domestic students (ISC president, personal communication, October 15, 2012). The lack of participation implies that few students value a visible and formal relationship between the university and the international students.

Increasing international and domestic student engagement was one of the goals of the strategic plan. The university implemented a multi-faceted approach in order to improve the international focus of the university. However, a major oversight in the approach involved the areas concerning interaction between international and domestic students, local ethnic communities involved in international student support, and the evaluation and improvement of the individual international student experience outside of the classroom. The plan summary is included to emphasize the oversight:

In 2007, the [university name omitted] embarked on a two-year assessment of its international activity, encompassing student mobility, faculty research, global visibility, engagement, accessibility of information, the role of the Office of International Affairs, and [university name omitted] position vis-à-vis our aspirational benchmarks.

Two areas that scholars have identified as important for the international student experience, intercultural interaction and local cultural immersion, are omitted. Such an oversight limits the success of the strategic plan.

Case study 1: Discussion. Based upon the description of the services offered at this southeastern university, it is not the legal, institutional/structural resources, nor the classroom pedagogy that is in question. Instead, international and domestic student interaction is the 
primary concern at the university. By encouraging increased interaction between international and domestic students, the cultural exchange can improve the academic experience of all students and simultaneously support public diplomacy.

However, encouraging intercultural student exchange can be difficult. Oftentimes, international students experience prejudice, negative stereotypes, and exclusion in and outside of the classroom. Likewise, domestic students express apprehension and reluctance when considering interacting with international students (Charles-Toussaint \& Crowson, 2010; Pandit, 2009). This can cause a campus to remain segregated and homogenous even with a diverse student population (Volet \& Ang, 1998; Petersen, Briggs, \& Dreasher, 1999). The university in the aforementioned case study is representative of such a space. Domestic and international student interaction is limited, and as a result, defined spaces, such as areas close to international dormitories and local ethnic neighborhoods, are reserved for international students; whereas, traditional domestic university spaces are dominated by domestic students.

There are two specific strategies that have been identified as viable options for improving this situation. First, Frey and Roysircar (2006) recommended continued and increased counseling and outreach that encourages greater international student adaptation to the host country. The second strategy has been to alter the social environments and attitudes of domestic students and local communities (Charles-Toussaint \& Crowson, 2010). Domestic students can also be at the center of host-nation, intercultural education exchange. CharlesToussaint and Crowson (2010) recommended such a focus after their research found that two of the four types of threat perception predict prejudice and negative relationships between American and international students.

\section{Case study 2: Mohamed Morsi}

Mohamed Morsi was formerly the fifth president of Egypt, and the first democratically elected president. Morsi was sworn into office on June 30, 2012 and served as the president until July 3, 2013. His term ended when he was relieved of his duties by the Egyptian military after protests from the Egyptian population. Morsi is a member of the Muslim Brotherhood (MB), a worldwide, social, political and religious (Islamic) organization with significant influence in the Arab world. He was the chairman of the Freedom and Justice Party (FJP), the political arm of the MB in Egypt, before running for the presidency in the 2011 Egyptian elections.

Morsi was educated in the United States. He received a Ph.D. in materials science from the University of Southern California in 1982 and was an Assistant Professor at California State University until 1985. Before becoming heavily involved in Egyptian politics, he held a position as a professor and head of the engineering department at Zagazig University until 2010.

Morsi's time spent in the United States offered the hope that the newly elected president would have some affinity for the United States' interests in the region as well as for the values, laws, and institutions that coincide with America's interpretation of democracy. As a result, some individuals believed that Morsi's American experience would be impetus for resolving a number of issues that plagued Egypt during Hosni Mubarak's rule, including human rights violations, repression of expression and religion, and issues of inequality (Blomfield, 2012).

Morsi's tenure did not progress as some hoped. He expanded executive powers without appropriate legal oversight and backed a questionable constitution that failed to guarantee and protect the rights of minorities and women. Both Western and Arab media outlets criticized the constitution's failure to outline government organization, its functions, and policies (Al Jazeera, 
2012; Carlstrom, 2012). A constant criticism of Morsi's time in office concerned the justification of his questionable actions by claiming majority will and majority rule. While the American version of democracy may possess its limitations and outright failures, based on Morsi's actions, he had not recognized the value in protecting the rights of minorities emphasized during the American civil rights movement nor the value and contributions of the United States diverse minority communities. Dissent and public political protests ensued until the Egyptian military intervened, unseating Morsi on July 3, 2013.

Case study 2: Discussion. There are many reasons for the current difficulties in Egypt that go well beyond public diplomacy. However, the tension, misunderstanding, and conflict experienced when interacting with a different culture can lead to identity issues. Identity concerns have been documented in both intercultural communication and international relations research, so their emergence should not come as much of a surprise in Morsi's case (Zaharna, 2000). Morsi's membership in the Muslim Brotherhood is one of the most significant issues. Scholars have described the MB as "an organization that sought nothing less than the transformation of society and the individual [in line with the tenets of Islam]" (Hamid, 2013, p. 3). Since altering a society to align more with Islam is not part of American international relations and diplomacy, an American and Morsi agreement on the direction of Egyptian democracy and governance was unlikely.

Trager $(2013,2011)$, outlined a number of additional reasons as to why an outcome favorable to American interests was unrealistic. First, the MB is a political organization focused on political uniformity, not compromise based upon political plurality. Secondly, there is a five to eight year initiation process before becoming a full-fledged $\mathrm{MB}$ member. This includes an oath to listen and obey. Ayman Nour of the secular Al Ghad party reiterated this point when discussing his parliamentary interactions with Morsi during Mubarak's tenure. Parliamentary requests designed for Mubarak had to be submitted through Morsi, but when given to Morsi, he would hold onto the requests, "pocketing the documents instead of passing them on, explaining that he couldn't sign until he'd gotten the opinions of all the Brotherhood's representatives" (Hammer, 2012, p. 21). The above episodes demonstrate just how entrenched Morsi was in MB cultural and political practices.

Unfortunately, Morsi represents a fairly common story for many international, and even national, out-of-state students. When confronted with a new culture, an individual will have to re-examine his or her identity and community, decide if and how to acculturate, and what new perspectives are worth adopting. Hammer (2012) noted that Morsi did little to reassess his understanding of the United States:

Although he [Morsi] admired the American work ethic, he chose to insulate himself from American society, spending much of his time with a small circle of fellow students from Arab countries... by the time he returned to Egypt in 1985, he was "dedicated to the [Muslim Brotherhood], a changed man. (p. 19-20)

When he expressed disdain for the "naked restaurants" such as Hooters, acquaintances had recognized that he had already extricated himself from the larger American society (Hammer, 2012, p. 20). Intercultural dialogue is one of the primary ways of negotiating confusing cultural phenomenon such as "naked restaurants," but within an insulated ethnic community, intercultural dialogue is difficult to conduct.

Another integral piece in Morsi's experience was the demands and heavy influence of his home community. The potential for increased affinity with the values and beliefs associated 
with American public diplomacy were substantially lowered in relationship to an integrated and culturally sophisticated home community organization. In an increasingly internationalized world, more and more individuals will rely upon their home community as an anchor when interacting abroad. In fact, similar reports about one of Egypt's interim presidents, General Abdel Fattah al-Sisi, have surfaced (see Kenner \& Lubold, 2013). While at a Super Bowl party, Sisi was more attracted to the host's collection of Islamic symbols and cultural artifacts than experiencing an American cultural phenomenon for the first time. This does not mean that Sisi will follow the same path as Morsi, but the reoccurring descriptions argue for the development of more well-researched strategies for international-education-public-diplomacy.

Increased intercultural integration and international conversations in American college and university settings could never offer a complete answer to the complex issues of concern in American and Egyptian relations. However, intercultural communication processes offer opportunities for the peaceful interaction of differing populations, especially in educational settings. Without an integrated and established cultural exchange, the beliefs and actions of individuals like Morsi and Sisi are understandable, if not predictable, and they serve as critical examples of the potential highs stakes of international education.

In Morsi's case, home community demands along with cultural isolation led to negative opinions of the United States. These outcomes highlight the importance of holistic international education support in order to avoid cultural misunderstanding. His case also identifies the need for identity management support that could be addressed through counseling, mental health, and wellness programs. Morsi's international student experience highlights the importance of intercultural dialogue, cultural immersion, and wellness services as aspects of an international student experience.

The international student may become the president of a country vital to a nation's international interests. In Morsi's case, one of the most pressing concerns was his position on the 1979 peace treaty with Israel (Blomfield, 2012). Morsi recognized the treaty, which alleviated some international anxiety of a renewed conflict between Egypt and Israel. Still, the outcome remained unclear until the treaty was signed, and the uncertainly unsettled the region. As mentioned throughout this paper, international students have a higher likelihood of obtaining influential positions in their host nations (Fulton, 2007). Thus, the consequences are intensified.

\section{International Student Experience and Public Diplomacy Limitations}

The theory of public diplomacy hinges upon idealism. More specifically, public diplomacy presupposes that cultural, educational, and private business efforts will be recognized and appreciated by the involved nations and their publics. In practice, benefit to the host and/or the home nation is much harder to measure. Patricia de Stacy Harrison (2008) and Lindsay (1989) warned that the underlying value in an education may take ten or twenty years to recognize. Any international education changes must consider the time involved in long-range policy and relationship improvement.

This issue highlights a significant tension underlying the merging of education and public diplomacy. The assumption is that there is something culturally valuable in the sharing of information and knowledge, and that not only does higher education lead to economic prosperity, but as Harrison (2008) believes, higher education leads to good citizens that contribute to their societies. 


\section{Conclusion}

The case studies presented in this paper raise a number of complicated and intertwined issues. First, while colleges and universities offer a wide array of resources and programs for international students, what needs are being met, how, and through what channels may not be accurately identified or employed. Furthermore, what characteristics and qualities international students find necessary for a successful experience at particular institutions may not be widely known or shared with the appropriate publics. The first case study reveals the importance of planning and resources dedicated to the outside-the-classroom elements that improve the international student experience, especially intercultural communication, interaction, and exchange. The second case study emphasizes the importance of intercultural dialogue, cultural immersion, and support for identity management for international students. Overall, the entire process of how to improve the international student experience would benefit from further macro-level, institutional, documentation, research, and initiatives.

There is no one certain way to improve the international student experience. What is most important is to acknowledge that the process "should be a comprehensive strategy that is built with input from the many stakeholders: faculty, students, alumni, and others" (Pandit, 2009, p. 654). A successful international student experience will most likely involve multiple strategies from different stakeholders. There is also a need for increased research into the cultural and intercultural aspects of international student education, and especially international student education as public diplomacy.

\section{REFERENCES}

Al Jazeera. (2012, November 24). Egypt: The president's new powers. Al Jazeera. Retrieved from http://www.aljazeera.com/programmes/insidestory/2012/11/ 2012112482649205402.html

Andrade, M. S. (2006). International students in English-speaking universities: Adjustment factors. Journal of Research in International Education, 5(2), 131-154.

Armstrong, L. (2007). Competing in the global higher education marketplace: Outsourcing, twinning, and franchising. New Directions for Higher Education, 140, 131-138. DOI:10.1002/he.287

Barge, J. K. (2006). Dialogue, conflict, and community. In J. G. Oetzel \& S. Ting-Toomey (Eds.), The Sage Handbook of Conflict Communication (pp. 517-543). Thousand Oaks, CA: Sage.

Bellamy, C., \& Weinberg, A. (2008). Educational and cultural exchanges to restore America's image. Washington Quarterly, 31(3), 55-68.

Blomfield, A. (2012, August 28). Mohammed Morsi vows to respect Egypt-Israel peace treaty. The Telegraph. Retrieved from

http://www.telegraph.co.uk/news/worldnews/africaandindianocean/egypt/9504601/Moha mmed-Morsi-vows-to-respect-Egypt-Israel-peace-treaty.html

Byrne, C., and Hall, R. (2013). Realising Australia's international education as public diplomacy. Australian Journal of International Affairs, 67(4), 419-438.

Carlstrom, G. (2012, October, 20). Political clash over Egypt's constitution. Al Jazeera. Retrieved from http://www.aljazeera.com/indepth/features/2012/10/ 20121019620186523.html 
Carroll, J. (2002). Suggestions for teaching international students more effectively. Oxford Centre for Staff and Learning Development. http://www.brookes.ac.uk

Charles-Toussaint, G. C., \& Crowson, M. H. (2010). Prejudice against international students: The role of threat perceptions and authoritarian dispositions in U.S. Students. Journal of Psychology, 144(5), 413-428.

Chau, A. (2011). OECD: International student number rises to 3.7 million. Retrieved from http://www.iu.qs.com

De Wit, H. (2002). Internationalization of Higher Education in the United States and Europe. Westport, CT: Greenwood.

Fischer, K. (2010). China props up foreign students' numbers in U.S. Chronicle of Higher Education, 57(13), A1-A25.

Frey, L. L., \& Roysircar, G. (2006). South Asian and East Asian international students' perceived prejudice, acculturation, and frequency of help resource utilization. Multicultural Counseling and Development, 34, 208-222.

Fulton, B. (2007). Geo-social mapping of the International Communications Environment or why Abdul isn't Listening. The Hague Journal of Diplomacy, 2, 307-315.

Hammer, J. (2012). The riddler: Understanding Mohamed Morsi. New Republic, 243(19), 19.

Higher Education and Public Diplomacy. (2008). International Educator (Washington, D.C.), 17(5), 16-20.

Kenner, D., \& Lubold, G. (2013, August 5). Sisi's year abroad. Foreign Policy. Retrieved from http://www.foreignpolicy.com/articles/2013/08/05/abdel_fattah_sisi_year_abroad_us_ar my_war_college_egypt

Leonard, M. (2002). Diplomacy by other means. Foreign Policy, 132, 48-56.

Lindlof, T., \& Taylor, B. C. (2011). Qualitative Communication Research Methods. Thousand Oaks, CA: Sage publication.

Lindsay, B. (1989). Integrating international education and public diplomacy: Creative partnerships or ingenious propaganda? Comparative Education Review, 33(4), 423-436.

Littlejohn, S. W. (2006). Moral conflict. In J. G. Oetzel \& S. Ting-Toomey (Eds), The Sage Handbook of Conflict Communication (pp. 395-418). Thousand Oaks, CA: Sage.

Mazzarol, T., \& Soutar, G. N. (2002). "Push-pull" factors influencing international student destination choice. International Journal of Educational Management, 16(2), 82-90.

McMurtie, B. (2012). China continues to drive foreign-student growth in the United States. Chronicle of Higher Education, 59(12), A18-A20.

Miller, A. D. (2013, February 27). Tribes with flags. Foreign Policy. Retrieved from http://www.foreignpolicy.com/articles/2013/02/27/tribes_with_flags_arab_spring_states

Nye, J. (2004). Soft power: The means to success in world politics. New York: Public Affairs.

Oetzel, J., Dhar, S., \& Kirschbaum, K. (2007). Intercultural conflict from a multilevel perspective: Trends, possibilities, and future directions. Journal of Intercultural Communication Research, 36(3), 183-204.

Olivas, M., \& Li, C. (2006). Understanding stressors of international students in higher education: What college counselors and personnel need to know. Journal of Instructional Psychology, 33(3), 217-222.

Pandit, K. (2009). Leading internationalization. Annals of the Association of American Geographers, 99(4), 645-656. DOI:10.1080/00045600903120552 
Petersen, D. M., Briggs, P., Dreasher, L., Horner, D. D., \& Nelson, T. (1999). Contributions of international students and programs to campus diversity. New Directions for Student Services, 86(Summer), 67-77.

President's Commission on Higher Education. (1948). Higher education for American democracy. New York, NY: Harper and Brothers.

Trager, E. (2011). The unbreakable Muslim Brotherhood: Grim prospects for a liberal Egypt. Foreign Affairs, 19. Retrieved from http://www.foreignaffairs.com/articles/68211/erictrager/the-unbreakable-muslim-brotherhood

Trager, E. (2013, January 28). Think again: Muslim Brotherhood. Foreign Policy. Retrieved from http://www.foreignpolicy.com/articles/2013/01/28/ think_again_the_muslim_brotherhood_egypt?page=0,0andwp_login_redirect $=0$

Tseng, W., \& Newton, F. B. (2002). International students' strategies for well-being. College Student Journal, 36, 591-597.

Volet, S. E., \& Ang, G. (1998). Culturally mixed groups on international campuses: An opportunity for inter-cultural learning. Higher Education Research and Development, $17(1), 5-23$.

Wang, J. (2006). Managing national reputation and international relations in the global era: Public diplomacy revisited. Public Relations Review, 32, 91-96.

Ying, Y., and Liese, L. H. (1994). Initial adjustment of Taiwanese students to the United States. Journal of Cross Cultural Psychology, 25, 466-477.

Yin, R. K. (2014). Case study research: Design and methods. Thousand Oaks, CA: Sage.

Zaharna, R. S. (2000). Intercultural communication and international public relations: exploring parallels. Communication Quarterly, 48(1), 85-100.

Zhai, L. (2002). Studying international students: Adjustment issues and social support. ERIC Document 474481.

\section{AUTHOR}

BENJAMIN TRIANA is a doctoral candidate in the Department of Communication at the University of Kentucky. His research interests include international and intercultural communication, cultural and media studies. Email: ben.triana0515@uky.edu 